Теорія літератури

Theory of literature
ISSN: 2411-6181(on-line); ISSN: 2311-9896 (print)

Current issues of social studies and history of medicine. Joint Ukrainian-Romanian scientific journal, 2017, №:3(15), P. 139-144 UDK $82-31^{\circ} 0$

DOI 10.24061/2411-6181.3.2017.95

\author{
ФУНКЦІОНАЛЬНЕ ЗНАЧЕННЯ ХРОНОТОПУ У РІВНЕВІЙ \\ СТРУКТУРІ ПРОЗОВОГО ТВОРУ (НА МАТЕРІАЛІ \\ СУЧАСНОЇ РОМАНІСТИКИ) \\ Антоніна АНІСТРАНЕНКО, \\ ВДНЗ України «Буковинський державний медичний університет», \\ Чернівці (Україна) \\ oirak@bsmu.edu.ua
}

\title{
THE FUNCTIONAL SIGNIFICANCE OF CHRONOTOP IN THE LEVELED STRUCTURE OF PROSE (BASED ON CURRENT NOVELS EXPIRIENCE)
}

Antonina ANISTRATENKO,

Higher State Educational Establishment of Ukraine

«Bukovinian State Medical University», Chernivtsi (Ukraine),

Researcher ID : S-7158-2016; ORCID ID 0000-0003-1984-4441

Анистратенко Антонина. Функциональное значение хронотопа в уровневой структуре прозаического произведения (на материале современной романистики). Пятиуровневая структура художественного произведения объединяет референтный, образный, языковой, текстуальное и кодовый уровне. Референтный - воплощает общую картину мира и концепцию человека, то есть опирается на природные знаковые системы. В теле произведения этот уровень соответствует организации художественного пространства и времени и структуры повествования. Они возникают как базовый, первичный уровень текстуальной реализации целостного произведения литературы. Так создается парадокс литературного чтения: разграничение времени и пространства в литературном тексте создает новую синкретическую сущность хронотопа в художественном произведении. Ведь литературный текст может быть охарактеризован как один из уровней художественного произведения и обнаружен как концепт, хронотоп, архетип времени или как линейное время. Следовательно, целью статьи является определение особенностей и своеобразия каждого из временных проявлений, как базовая характеристика литературного текста в теории структурализма.

Ключевые слова: литературное произведение, текст, уровни художественного произведения, кониепт времени, архетип времени, хронотоп.

Вступ. Якщо розглянути художній твір засобами структурного аналізу, то його, незалежно від роду, можна представити у розрізі п'яти рівнів. Кожен із репрезентативних рівнів об'єднує певні характеристики, означивши які, можна у висновку аналізувати весь твір загалом, що і ставить перед собою за мету дослідник, послуговуючись досягненнями структуралізму.

Відтак, п’ятирівнева структура художнього твору об'єднує референтний,образний, мовний, текстуальний та кодовий рівні. Референтний - втілює загальну картину світу та концепцію людини, тобто спирається на природні знакові системи. У тілі твору цей рівень відповідає організації художнього простору та часу й структури оповіді. Вони постають як базовий, первинний рівень текстуальної реалізації цілісного твору літератури.

Постановка проблеми. Перший, базовий, щабель художнього твору - референтний - втілює в собі квінтесенцію фабульного контенту твору, адже уособлює хронотоп, а отже являє собою подієву мапу тексту. Тому 3'ясування теоретичного підгрунтя побудови часопростору дає підстави аналізувати художній текст засобами структурного аналізу не лише на рівні ідейнотематичному, але й глибше - на рівні залягання письменницьких ідей прослідкувати появу i «зростання» твору. Мета пропонованої статті - розглянути вияви літературного часу в художніх творах сучасної української літератури та зіставити їх із реальним часом, задля 3'ясування особливостей розробки письменником когнітивного часопростору прозового твору.

Історіографія питання. Аналітичний розгляд часопросторової організації твору щільно пов'язаний 3 концепцією хронотопу М. Бахтіна і передбачає відокремлену характеристику художнього часу, художнього простору та аспектів їх емоційно-ціннісного забарвлення, які в літературному творі перебувають у єдності. Література, на думку Б. Успенського «передусім пов'язана не 3 простором, а 3 часом» ${ }^{1}$.

Відтак, перевага часу над простором закладена, на думку Н. Астрахан ${ }^{2}$, у природній мові як матеріалі для літератури. Цікавим фактором поєднання часу і простору, тобто функціонування хронотопу в художньому твоpi, $\epsilon$ те, що літературний час може перетворюватись на літературний простір і обидва типи функціонування хронотопу закладені у ньому знаковою системою - мовою. Однак, на думку М. Мамардашвілі, ані час, ані простір, ані їх зв'язок - хронотоп, у літературному творі не стають універсальними: йдеться про характерні риси конкретного гатунку ${ }^{3}$.

Виклад основного матеріалу. Розщеплення об'єк-

\footnotetext{
${ }^{1}$ Uspenskiy B. A. Struktura khudozhestvennogo teksta i tipologiya kompozitsionnoy formy [The structure of an artistic text and typology of a composite form], Moskva, 1995, P. 103.

${ }^{2}$ Astrakhan N. Buttya líteraturnogo tvoru: Analítichne ta ínterpretatsíyne modelyuvannya: monografíya [The Origin of a Literary Work: Analytical and Interpretative Simulation: Monograph], Kyiv, Akademvydav, 2014, P. 183.

${ }^{3}$ Mamardashvili M. K. "Prevrashcheniye formy (O neobkhodimosti irratseonal'nykh vyrazheniy)" [Transformation of the Form (On the Need for Irrational Expressions)], Formy i soderzhaniye myshleniya, SPb: Azbuka; Azbuka-Attikus, 2011, P. 23.
} 
та і його людської моделі, що відбувається внаслідок абстрактного оперування фактами час і простір, долається в літературному творі, в якому художній хронотоп стає передумовою створення цілісних картини світу та особистості, що можуть бути усвідомлені як концепція. Так витворюється парадокс літературного прочитання: розмежування часу і простору в літературному тексті створює нову синкретичну сутність хронотопу в художньому творі. Адже літературний текст може бути схарактеризований як один із рівнів художнього твору і виявлений як концепт, хронотоп, архетип часу або як лінійний час.

Концепт часу. Концепт часу співвідноситься 3 антропологічним розумінням часовості. Це важливий аспект для укладення певної системи в компонентах картини світу та іiї проекції в художньому творі. Адже художній твір завжди виступає моделлю часткового уявлення про світ, яке вічно прямує до повноти. Отож системність виявляємо і в компонентах твору одним 3 яких $є$ концепт часу.

Детермінованість часу в трьох формах дійсності виявляється і в концепті часу, хоч і меншою мірою, ніж у хронотопі. К. Ясперс виявляє цю рису в деструктивному світлі скептицизму: «Минуле міститься в нашій пам'яті лише уривками, майбутнє - темне. Тільки теперішне могло би бути осяяне світлом. Адже ми повністю занурені в нього. Однак саме воно виявляється непроникним, тому що 3'ясованим воно було б лише при повному осягненні минулого, яке стає його основою, і майбутнього, яке таїть його в собі» ${ }^{4}$.

За словесною еквілібристикою виринає зміст важливої ідеї, що концепт часу в літературному творі завжди перебуває під впливом первинного концепту простору, простору, що дорівнює первинному поняттю буття, існування, яке передує триванню.

Хронотоп літературного твору значно більше піддається схематизації. На відміну від концепту й архетипу часу, є частиною архітектоніки тексту. 3 певною долею узагальнення хронотоп можна віднести до плану форми (вираження). Першим цей термін ввів визначний біолог А. Ухтомський. За М. Бахтіним, який поширив термін в літературознавчій галузі знань, «Хронотоп в литературе имеет существенное жанровое значение. Можно прямо сказать, что жанр и жанровые разновидности определяются именно хронотопом, причем в литературе ведущим началом в хронотопе является время» 5 . Ось одна 3 когерентних ознак твору. Хронотоп, це не просто час-простір твору, а конкретний формальний чинник, який для прозового роду літератури визначає вид, і часто - навіть жанр.

В усталених сюжетних схемах за типом хронотопу визначаємо такі види роману: історичний роман (хронотоп лінійний, переважно розгортається в минулому), фантастичний роман (хронотоп циклічний, переважно розгортається в теперішньому-майбутньому), детективний роман (хронотоп інверсійний, розгортається з теперішнього в минуле).

Лінійний час. Цікаво в цьому ключі розглянути реалізацію (сприйняття) теперішнього, минулого, майбутнього, які виявляються складовими хронотопу.

Теперішне, яке існує лише умовно, і «виражає відносну стійкість в процесі безперервної зміни [...] в дискретній природі матеріального світу теперішнє завжди співвіднесено з яким-небудь станом, й за триванням цієї події, стану визначаємо розміри теперішнього, причому в кожному конкретному подієвому ряді це визначення специфічне. Різна тривалість теперішнього $\epsilon$ однією 3 характерних рис проявлення специфіки часу...» ${ }^{6}$. В драматичному творі теперішній час триває протягом реалізації в свідомості реципієнта кожної дії. Поетичний твір - цілком перебуває у теперішньому. А прозовий жанр має лише моменти теперішнього часу.

Минуле в цій парадигмі характеризується нескінченним триванням, по-перше, тому, що майбутнє лише проектоване, а не відоме й тому може нескінченно віддаляти минуле від теперішнього моменту часу, подруге, тому, що минуле в певному сенсі творить реальну тяглість часу й у ній увіковічнюється. В практичному вимірі, тобто, в хронотопі літературного тексту минуле виявляється в послідовності причинно-наслідкових зв'язків подій.

Майбутнє - це часова проекція потенцій предметів та явищ простору. В літературному творі множинність майбутнього на рівні рецепції втілюється в численних варіантах розвитку подій, які виникають у свідомості читача під час ознайомлення 3 текстом і в свідомості автора під час його творення. Система замикається при завершенні дискурсу твору (творчого чи рецептивного). «Майбутнє - це об'єктивна тенденція становлення предмета, що виражається в наявності умов для його виникнення» ...»7 . Так, майбутнє у хронотопі твору відповідає авторському я, втіленому на референтному рівні.

Архетип часу. Найкоротше і найзагальніше визначення, яке нам вдається виокремити із десятків співіснуючих дефініцій архетипу, таке: архетип - цее наскрізний первинний символ колективної свідомості. Якщо виводити це поняття поза межі національної картини світу і розглядати на рівні цивілізаційному, тоді на тлі найзагальніших образів проявляється архетип часу. Порівняно 3 такими архетипами, як земля, вода, вогонь, повітря, добро, зло, матір, батько, сила, ворог, дім, архетип часу молодший, тобто пізніший.

Якщо співвідносити його 3 певним функціональним розумінням часу, то темпоральний архетип відповідає філософському сприйманню часу.

В літературі архетип часу реалізується не в первинному його значенні - абстрактної часовості. Отже, щоб дослідити реалізацію архетипного значення часу в літературному творі необхідно занурити нещодавно вбудований у цивілізаційний простір архетип знову в

\footnotetext{
${ }^{4}$ Yaspers K. Smysl i naznacheniye istorii [The meaning and purpose of history], Moskva, 1991, P. 141.

${ }^{5}$ Bakhtin M. "Formy vremeni i khronotopa v romane. Ocherki po istoricheskoy poetike" [Forms of time and chronotope in the novel. Essays on Historical Poetics], Voprosy literatury i estetiki. Moskva, Khudozh. lit., 1975, Р. 234. - «Міфологічний час сприймається як такий лише в ретроспекції, у світлі пізнішої звички мислити лінійно протікаючу розчленовану тривалість як невід'ємну структурну властивість життя. Для древніх він був не стільки часом, скільки відсутністю часу, який саме цією відсутністю, перебування м поза змінами, рухом, розвитком, взагалі поза акциденцією, і характеризував особливий, нерухомий та цінний стан дійсності» [перекл. авт.].

${ }^{6}$ Askin YA. Problema vremeni, yeye filosofskoye istolkovaniye. [The problem of time, its philosophical interpretation], Moskva, 1966, P. 85.

${ }^{7}$ Ibid, P. 86.
} 
середовище національної семантичної полярності. Власне, літературний архетип часу побутує у формі національно-ментального явища. Більшою мірою через національну специфіку літературного методу відображення світу, ніж походження символу. Про походження архетипів взагалі мову не ведемо: коли говоримо про зчитування архетипного символу автором певного літературного твору, то маємо на меті вказати на спосіб, засіб, мету інтерпретації його.

Важливою рисою архетипного часу вважаємо ту, що виводить його з площини дуальності, маємо на увазі, що темпоральному архетипу немає протиставлення, антонімічної пари. Він такої й не потребує. Помилково вважати антиподом часу - простір. Ототожнювати їх або поєднувати так само недоцільно, якщо йдеться про архетипи.

I нарешті останньою загальною характеристикою архетипу часу є його прив' язаність до теперішнього (яку іноді розглядають як нерухомість, спрямованість на вічне тривання). Це наріжний камінь архетипу часу в літературі. Літературний твір завжди творить історію, тож архетип часу проходить зміни для такого перетворення - інтерпретацію.

«Не існує історії теперішнього... вона могла би бути лише провіщенням того, що про нас напишуть майбутні історики... якби таке оповідання могло би бути написаним і впізнаваним нами, ми могли б його, в свою чергу, заперечити, діючи на противагу його передреченню... Твердження П. Рікера, що майбутнє відкрито, означає наступне: ніхто не написав історію тепеpiшнього. Це останнє зауваження приводить нас до... внутрішньої межі оповідних висловлювань» ${ }^{8}$. Подолання цієї своєрідної межі пов'язане 3 інтерпретацією. Інтерпретація виявляється в затребуваності реліктового надпоняття - архетипу (часу) в звиклі для нас (в разі літпродукту - правдоподібні відображення ймовірного світу) категорії триванння.

Альтернатива моменту часу. Альтернатива моменту часу, перебуваючи поза ним, одночасно створює іiі в собі. Причини цього парадоксу лежать глибоко в генеалогії поняття моменту: «Слово «момент» має два значення, які походять одне від одного: технічне (механічне) та часове» ${ }^{9}$.

В часовому значенні, «момент» - цілком зрозумілий і звичний для всіх термін означає невеликий проміжок часу, але також поняття момент має значення «моменту сили», тобто механічної дії, яка змінює попередній простір, зрушуючи об'єкти в ньому. Відтак саме у якості «моменту» час реалізується в творах малої прози, незалежно від конкретної значеннєвої «сходинки» часу: концепту, архетипу чи своєрідного хронотопу. Альтернативність проявляється у моментальності часу, розщепленні його на один момент або їх обмежену множинність. Тоді альтернативність подій прямо залежить від кількості і якості його моментів. Якщо в новелі або оповіданні маємо один тяглий у розгортанні сюжету момент, зображений пере- важно настроєво - описаним станом героя, то альтернатива може мати прихований характер і належить вже до процесу рецепції читачем, а саме: до фази когнітивного співвіднесення художньої дійсності та реальності.

Наприклад, у оповіданні С. Кононенко «Зустріч у Сан-Франциско» ${ }^{10}$ в основі сюжету лежать спогади сорокарічної жінки про мандри відомими у світі містами та, зокрема, про доленосну зустріч у Сан-Франциско, то персонаж оповідання відтворює альтернативний реальному світ спогадів. Теплі спомини про власніі враження моменту в минулому, який запам'ятався райдужною панорамою, замінюють у пам'яті не тільки емоційне забарвлення подій, а й самі факти. Скажімо, авторка пише від імені героїні про місто Сан-Франциско (США), як про об'єкт бажання [див. розділ «Політична історія України - поле для боротьби science fiction та nonfiction»]. Оскільки вона бажає відвідати це місто i здійснити омріяну зустріч, то підсвідомо описує бажану реальність кращою, ніж та насправді $\epsilon$, створюючи тим самим альтернативну історію в майбутньому i, розповідаючи іiі, - вже у минулому. «Ще від зими вони почали радісно планувати подорож до Сан-Франциско, у райський куточок між океаном і затокою, де влітку температура не сягає вище +30 градусів, а взимку не падає нижче $-20 » 11$.

У реальності ж, місто Сан-Франциско - таке ж місто, як й інші міста Америки, або Європи, хоча б у тому сенсі, що погодні умови там мінливі, а люди живуть, як і скрізь, по-різному. Скажімо, наразі, у середині серпня, там +13 градусів і досить вітряно, але для ототожнення його 3 «райським куточком» письменниці необхідно було у певний момент часу створити альтернативний простір до реальності. Відтак, у цьому оповіданні Є. Кононенко можна говорити про альтернативний психолого-емоційний зріз міста, тобто альтернативність у оповіданні - це момент не хронотопу (референтного рівня), а образного рівня твору. Адже, як справедливо пише Максим Розумний про сучасну українську прозу: «В теперішній літературі ключовим $є$ момент втручання у перебіг подій суб'єктивного сприйняття реальності самим героєм. Його власне уявлення про можливе i неможливе, гідне i негідне, починаючи 3 очевидністю впливати на довколишню реальність, формувати іï» ${ }^{12}$.

Однак альтернативна історія на сучасному етапі не просто жанр, а жанровий конструктор, метажанр. Тому альтернативність зароджується на різних рівнях твору i, відповідно, належить до різних знакових систем: від кодового рівня зі знаковою системою математичних символів, що на текстуальній реалізації містить програми інтерпретаційних моделей та ограничує феномен номінації, до референтного рівня природних знакових систем, що на текстуальній реалізації постає організацією художнього часу та простору й структури оповіді (за Н. Астрахан). Літературний текст у якому виникає альтернативність подієвого ряду, перебуває у мейнстрімі альтернативноісторичних текстів. Треба за-

\footnotetext{
${ }^{8}$ Riker P. Vremya i rasskaz [Time and story], Vol. 1, Moskva, SPb, 2000, P. 171.

${ }^{9}$ Yevropeys'kyy slovnyk filosofiy: Leksykon neperekladnostey [European Dictionary of Philosophy: Lexicon of Implications], Vol. 1, Vyd. druhe, vypravl, Kyiv, Dukh i Litera, 2011, P. 379.

${ }^{10}$ Kononenko Ye. "Zustrich u San-Frantsysko" [Meeting in San Francisco], Pokhid cherez zasnizhenyy pereval, Kyiv, Presa Ukrayiny, 2013, 384 p.

${ }^{11}$ Ibid., P. 146.

${ }^{12}$ Teksty: antolohiya prozy [Texts: Anthology of prose], Uporyad. A. Kokotyukha ta in., Kyiv, Smoloskyp, 1995, P. 293-294.

Ibid., P. 337.
} 
уважити, що навіть така, сказати б, очевидна річ як події у їх послідовності, що складають альтернативну реальність по відношенню до дійсності, не убезпечують літературний текст, що у висновку стає твором, від фальшування жанру.

Візьмемо, до прикладу, дебютний цикл оповідань, об'єднаних у епічний твір, Макса Кідрука «Мексиканські хроніки» (2009). Типова альтернативна історія подорожі, де сам стан подорожування має формат надпозитивної оцінки: всі складні моменти подорожування, починаючи 3 вивільнення особистого часу мандрівника на здійснення омріяного задуму, до оформлення документів та, власне, самої подорожі з перельотами і переїздами, що не завжди просто і комфортно відбувається в дійсності, особливо з українським громадянством, виглядають неймовірно привабливими у літературному тексті, а навіть карколомні і небезпечні події, представлені автором з гумором і життєлюбством бувалого мандрівника, у монографії про сучасну українську белетристику проаналізовано у чудернацький спосіб.

Книга, яка, очевидно, покликана служити дороговказом у розбурханому морі сучасної прози, може заплутати в жанровій оцінці творів не тільки читачів, але й самих їхніх авторів, оскільки невідомий автор розділу, присвяченого творчості М. Кідрука вважає, що «Окреслити цей жанр точно - непросто, а то й неможливо» ${ }^{13}$. Пояснюється специфічна жанрова картина тим, що, на думку автора розділу, «загальновідомо, що література мандів $€$ синтетичним утворенням. Вона балансує між белетристикою й публіцистикою, фіктивністю й документальністю» ${ }^{14}$. 3 погляду жанрології, весь розділ репрезентує новину під грифом «без коментарів», коли стається так, що жанровим маркуванням твору займаються люди, компетенція яких у цій справі далеко неочевидна: сам автор (у нашому випадку технічного фаху), його друзі та читачі, журналісти широкого профілю, блогери.

«Чи не постала в результаті саме та читабельна й серйозна «мідл»-література, література «середнього пласту», екзистенційна психологічна проза», про потребу якої в національному письменстві говорив I. Андрусяк?» - запитує, достеменно не зрозуміло кого, автор розділу «Мексиканські хроніки» Максима Кідрука: квест по-українськи» ${ }^{15}$. Відповідь: однозначно і цілковито - ні.

Відтак, усіма переліченими характеристиками послуговуються літературознавці, втрапляючи в пастку фіктивних «першоджерел». Хоча основним джерелом для визначення жанру $\epsilon$ літературний текст. А він підказує реципієнтові, що мандри - тільки тло розгортання історії подорожі, такої, що в реальності, іiі, з багатьох причин, здійснити неможливо (у «путівнику» не знайдеться реальних туристичних, таких, як було описано, фірм чи авіакомпаній $з$ щогодинними вилітами до Мексики просто з Бориспілького аеропорту) і зупинитися в тому самому хостелі, де автор ніби-то познайомився 3 деякими персонажами майбутніх «Мексиканських хронік» не вийде, просто тому, що художній час i простір наразі не існує і в кожного мандрівника - своя подорож. Ідеться про альтернативну історію подорожі, що жодним чином не применшує іiі привабливості, а швидше - навпаки.

Ось ми розглянули два види альтернативізму: подієвого (на образному рівні твору) та референтному (організація хронотопу i структура оповіді 3 ïx співвіднесеністю до реальності).

Однак, не менш цікаві твори, переважно урбаністичного характеру, в яких альтернативність виявляється на текстуальному та мовному рівнях, що відповідно означують авторські інтерпретаційні моделі та омовлений рівень літературного тексту. Це твори, де згущений хронотоп унікально проявляється у перевазі простору над часом, а час стає реліктом сприйняття. Момент набуває механістичного, а не часового значення. образи втрачають тяглість i набувають універсальних рис, а історія настає поза часом і в кожен момент, який стає лінією вісі обертання подій, здобуває альтернативу повної реалізації.

Тут варто на хвилю залишити спостереження української літератури і звернути свій зір на німецьку літературу. Першим автором, що написав оповідання альтернативного урбаністичного характеру, описавши подорож до містаз подвійним обличчям, одне 3 яких справжнє, а друге стає авторською візією, був німецький прозаїк i філософ Германн Гессе i його «Паломництво в країну Сходу». Відтак, виходить ненавмисне створена альтернативна історія. Адже кожне реальне місто веде нескінченну війну 3 часом (пісня гурту Мері «Місто»), міський силует, що потрапляє на сторінки правдивої авторської історії існує поза часом, тобо є візією міщанина-автора, якщо, звісно, йдеться не про туристичний буклет. Отож, «Die Morgenlandfahrt» ${ }^{16}$ характеризується на мовному i текстуальному рівні альтернативністю сприйняття місць та міст на геополітичній мапі сучаного авторові світу, це справжня подорож у невідому країну і світ, які так легко знайти на карті, але неможливо відвідати.

Вчасно повертаючись до української літератури та українського грунту, звернемо увагу, в згаданому сенсі, на невеличке оповідання-нарис Карла Еміля Францоза, австрійця, що писав німецькою мовою, зате про Чернівці, «3 Відня до Чернівців». Протягом залізничної подорожі автор перебуває у суперечливому діалозі 3 сусідкою по купе про межі і кордони Європи та Азії, які він спробує визначити за краєвидом за вікном та особистим відчуттям у просторі сіл та міст, якими прямує потяг. I ось, потяг Францоза прямує через «коров' ячий край» і також місцини, де чути польсько-німецьку мову, сморід і жінок, одягнутих без жодного естетичного смаку, кафе, в яких ніколи не бачили білих скатертин і нарешті спиняється у Чернівцях: «Чудово розкинулось місто на високому схилі. Тому, хто прибуває сюди, робиться якось дивно на душі: він раптом знову на Заході, де можна зустріти освіченість, вихованість і білу скатертину» ${ }^{17}$.

\footnotetext{
${ }^{13}$ Suchasna ukrayins'ka beletrystyka: koordynaty «Koronatsiyi slova»: monohrafiya [Contemporary Ukrainian Fiction: Coordinates of the Coronation of the Word: monograph], Mykolayivs'kyy natsional'nyy universytet im. V. O. Sukhomlyns'koho, za zah. red. S. V. Pidopryhory, Mykolayiv, Ilion, 2014, P. 283.

${ }^{14}$ Ibid.

${ }^{15}$ Ibid., P. 282-283.

${ }^{16 /}$ Ibid., P. 282-283.

${ }^{17}$ Potyah nadiy ta inshi zaliznychni spoluchennya [Train hopes and other rail connections], L'viv, VNTL-Klasyka, 2011, P. 62.
} 
Отже у малій прозі української літературної традиції потрійний у своєму вияві момент часу, що розгортається як архетип, концепті хронотоп, одержує альтернативність за описаною схемою на чотирьох із п'яти рівнях художнього твору.

3-поміж усіх текстів В. Кожелянка у новелах та оповіданнях книги «Чужий» найповніше та найрозмаїтіше реалізований архетип часу. Струнка композиція та відсунення використання часопростору, як двох осей системи координат на другий план, вивільнюють для В. Кожелянка безмежне різноманіття сюжетних альтернатив та чотири виміри для розвитку діï. Ні час, ні простір не диктують умов дії. Лише сама людина, персонаж, як ми вже згадували, веде себе від гріха до покаяння, від вибору до наслідку, від втечі до повернення і це змушує героя бути сильним, бути дієвим і відповідальним.

У новелі «Українська книга мертвих» ${ }^{18}$ автор нагадує українцям, що ми за довгий шлях національної, хоч і недержавної історії, не лише не навчились жити, більше того, не навчились навіть помирати. На кшталт «Тибетської книги мертвих», «Єгипетської книги мертвих» В. Кожелянко, устами персонажа Єрофантенка, пропонує створити «Українську книгу мертвих» і під час обдумування цієї ідеї приходить до цікавих висновків. Переважно «афоризми» стосуються часу життя людини, його тяглості та відповідності об'єктивному часові. Час життя асоціюється 3 архетипним символом часу, оскільки береться до уваги, як такий, абстрактний, незалежно від кількості років життя. Натомість плин часу в житті залежить від поведінки самої людини: «...бо той, хто не прожив повноцінно земне життя, випереджував події, вмирав не насправді, а так собі, знічев'я, через млявість волі, той отримує у потойбіччі великі проблеми. Бо як він жив, як мертвий, то й вмирає, як мертвий...» ${ }^{19}$. Потойбіччя письменник оцінює як позачасовий вимір. Так, життя існує лише в часі. А українець сприймає все навпаки й починає бачити людину в людині вже після їі смерті: «Він [українець] переносить своє ставлення до людини, якої вже нема, на iii труп, і вибудовує культ померлого. Малює портрети трупа, ставить пам'ятники трупу...» ${ }^{20}$. Але і 3 цього сумного правила існують ще сумніші винятки - дехто не тільки живе, як мертвий, але вже народжується мертвим. Чи живе він насправді? Чи має для цього час? Відповідь доведеться придумувати самому читачеві.

У романах, створених у жанрі альтернативної історії, неодмінним елементом сюжету є зміна історії в минулому. За ідеєю автора, в деякий момент минулого, 3 якої-небудь причини, або випадково, або в результаті втручання зовнішніх сил, наприклад, прибульців із майбутнього, відбувається щось відмінне від того, що відбувалося в реальній історії. Те, що сталося, може бути пов'язане 3 широко відомими історичними подіями чи особами, а може видаватися, на перший погляд, малозначимим. У результаті цієї зміни відбувається «розгалуження» історії - події починають розвиватися за іншим сценарієм. У світі зі зміненим хронотопом і відбувається дія.

Першим романом у жанрі альтернативна історія був роман на тему Другої світової війни - це «Дефіляда в Москві». «Роман-анекдот №1, тобто «Дефіляда», довів, що майбутнє - це добре сплутане, з неочікуваним фіналом, минуле. Тим паче, коли йдеться про літературний твір. Багатьма літературознавцями й звичайними читачами вона сприймається, як анекдотичний продукт, створений за допомогою зміщення часових площин та історичних фактів» ${ }^{21}$. Насправді ж, автор змінює точку зору на події, їх причини та наслідки, причому, - у прямому значенні. Знову час виявляється в хронотопному вигляді, бо підпорядкований вимозі необхідного авторові простору. Кожелянко навмисно не показує часових проміжків, необхідних для такого діаметрально протилежного перетворення менталітету українців.

Висновки. Підсумовуючи короткий огляд часових виявів у прозовій творчості Василя Кожелянка, можемо аргументовано зауважити роль часу як концепту, хронотопу та архетипу. У романах political fiction зміна часового плину чи співвідношення минуле-теперішнєсучасне відіграє жанротворчу роль, у фантастичних пригодницьких творах час=простору, в історичному пригодницькому романі час $є$ компонентом дії - персонажем, а в романі політичному-анекдоті - час виступає вказівником, «свічкою чительника» (І. Франко).

У малій прозі час виконує ті ж функції, що й у епічних творах великих жанрів, щоправда, його якості змінюються: час новели найчастіше $\epsilon$ реліктовим, «загуслим», таким, що не має тяглості. Часто хронотоп новели заміняє момент часу. Відповідно хронотоп і його сюжетний відповідник - подієвий ряд - спостерігаються читачем, наче в музеї історії, ніби експонат за склом або невеликий острівець 3 висоти пташиного польоту. Момент часу в новелі заміняе період часу, в той час як в оповіданні все ж таки має місце невеликий часовий проміжок і хронотоп залишається в його класичному прозовому варіанті.

I хоч, на думку М. Бахтіна, літературний час може бути об'єктивним, наприклад в епопеї, на практиці бачимо, що час літературного твору завжди виступає елементом гри, як і сам літературний твір $\epsilon$ «начебто реальністю» ${ }^{22}$. Це зовсім не применшує значення ні твору, ні часу. Зате розкриває ті можливості, яких ми не маємо в справдешній реальності - в житті.

Anistratenko Antonina. The functional significance of chronotop in the leveled structure of prose (based on current novels expirience). The five-level structure of a prose itemt combines reference, figurative, linguistic, textual and code levels. Reference one parcipate the general worldview and the concept of man, that is based on the natural sign systems. In the body of the text this level corresponds to the organization of the artistic space and the time and structure of the narrator. It appears as a basic, primary level of textual realization in the holistic work of literature. In such way the paradox of literary reading uses to be: the delineation of time and space in the literary text creates a new syncretic

\footnotetext{
${ }^{18}$ Kozhelyanko V. Chuzhyy. Novely [The extraneous], Lviv, Kal'variya, 2008, P. 124-157.

${ }^{19}$ Ibid.., P. 131.

${ }^{20}$ Ibid, P. 135.

${ }^{21}$ Anistratenko A. "Dolya ukrayins'kykh intelektualiv. Zustrich-interv"yu z istorykom, politolohom, publitsystom Ihorem Burkutom” [The fate of Ukrainian intellectuals. Meeting-interview with historian, political scientist, publicist Igor Burkut], Universytet $\cdot \mathrm{s}^{\prime} \mathrm{kyy}$ visnyk, 2012, lyutyy-berezen' (№2), P. 33.

${ }^{22}$ Bakhtin M. Literaturno-kriticheskiye stat'i [Literary and critical articles], Moskva, Khudozhestvennaya literatura, 1986, P. 301.
} 
essence of the chronotop in the artistic text. After all, literary text could be described as one of the levels of artistic text and is identified as a concept, chronotope, archetype of time or as linear time. Therefore, the purpose of the article is to outline the peculiarities and peculiarities of each of the temporal realisations as the basic characteristics of the literary text in the theory of structuralism.

The concept of time correlates with the anthropological understanding of time. After all, an artwork serves always as a mode of a partial representation of the world, which runs to fullness forever. So the system is detected using the components of the artistic product, one of them is the concept of time. The chronotop of the literary work is much more subjective to schematization. Unlike the concept and archetype of time, it is part of the architectonics of the text. In fixed plot schemes it identifites by the type of chronotope and use to be determined by the following types of novel: the historical novel (the linear chronotope, mostly unfolding in the past), a fantastic novel (the cyclonic chronotope, mostly unfolding in the present and future), a detective novel (the inverse chronotope unfolding from the present to the past). The archetype of time like a concept that works beyond the boundaries of the national worldview and considered at the level of civilization that is on the background of the most general images and realizes an archetype of time. It could be compared with such archetypes as Earth, Water, Fire, Air, Good, Evil, Mother, Father, Force, Enemy,
Home, archetype of Time is a little bit later. If to use it likely correlated with a certain functional sense of time, then temporal archetype corresponds to the philosophical perception of time.

Key words: literary work, text, levels of artistic text, concept of time, archetype of time, chronotope.

Аністратенко Антоніна - кандидат філологічних наук, викладач кафедри суспільних наук та українознавства ВДНЗ «Буковинський державний медичний університет». Коло наукових інтересів: сучасний арт-процесУкраӥни, Польщі, Німеччини, Австрії, Швеиії. Автор 79 наукових праць, статей, розвідок, у тому числі 3 монографій.

Anistratenko Antonina - PhD, lecturer of the Department of Social Sciences and Ukrainian Studies, Higher State Educational Establishment of Ukraine "Bukovinian State Medical University». Research interests: modern art process in Ukraine, Poland, Germany, Austria and Sweden. Author of 79 scientific publications including 3 monographs.

Received: 17.04 .2017

Advance Access Published: June, 2017

(C) A. Anistratenko, 2017 